\title{
Surprising Changes in Aerosol Loading over India amid COVID-19 Lockdown
}

\section{Aerosol and Air Quality Research}

Special Issue:

Special Issue on COVID-19 Aerosol Drivers, Impacts and Mitigation (XI)

\section{Satyendra K. Pandey* , V. Vinoj}

School of Earth, Ocean and Climate Science Indian Institute of Technology Bhubaneswar, Jatni 752050, Odisha, India
Using ground-based and satellite observation along with aerosol reanalysis products, we show a widespread reduction in aerosol loading over the Indian subcontinent during the COVID-19 (COronaVIrus Disease 2019) lockdown. The pre-lockdown and lockdown period considered in the present study is $20^{\text {th }}$ February-20 $0^{\text {th }}$ March 2020 and $24^{\text {th }}$ March-22 ${ }^{\text {nd }}$ April 2020. In terms of aerosol optical depth (AOD), loading has reduced up to $40 \%$ over the most populated region of India. However, the central part of India shows an unexpected increase $(\sim+20 \%)$ in AOD. A simultaneous increase (decrease) in mid-tropospheric relative humidity (wind speed (WS) at $850 \mathrm{hPa}$ ) by $+85 \pm 6.0 \%(-12 \pm 3.9 \%)$ occurred during the lockdown. It is found that on a daily scale, the mean AOD is positively (negatively) correlated with mid-tropospheric RH (WS) with a statistically significant linear correlation coefficient of $0.53(-0.43)$. An increase (decrease) in $\mathrm{RH}$ (WS) of $20 \%\left(1 \mathrm{~m} \mathrm{~s}^{-1}\right)$ was observed to increase AOD by 0.10 (0.04). Thus, we hypothesize that during the lockdown, the increased AOD over central India was due to increased atmospheric moisture coupled with stagnant circulation condition.

Keywords: COVID-19, Lockdown, Aerosols, Air pollution, Humidity

\section{INTRODUCTION}

The World Health Organization (WHO) declared a global health emergency in January 2020 due to the newly found contagious coronavirus disease named COVID-19. The virus (SARS-CoV-2, Severe Acute Respiratory Syndrome-CoronaVirus-2) responsible for it is of zoonotic origin and was first reported in Wuhan, China, during late December 2019 (Huang et al., 2020; Zhou et al., 2020). Globally, the total death toll of 484,249 and the number of reported cases reached $9,473,214$ (as of $26^{\text {th }}$ June 2020) (WHO, 2020). This pandemic caused an unprecedented response from the countries leading to a complete or partial shutdown of human activities. Governments in the South Asian regions, including India, also announced nationwide lockdown in the late March 2020, confining residents to their home except essential services.

Studies across the globe reported a significant change in various environmental and ecological indicators due to limited human activity. Whereas lockdown improved air and water quality (Chauhan and Singh, 2020; Paital, 2020; Yunus et al., 2020), reduced $\mathrm{CO}_{2}$ (carbon dioxide) level (Le Quéré et al., 2020), cleaned beaches, bloomed wildlife, it adversely affected waste recycling (Zambrano-Monserrate et al., 2020). Primary air-pollutants like $\mathrm{NO}_{2}$ (nitrogen dioxide), $\mathrm{SO}_{2}$ (sulfur dioxide), $\mathrm{CO}$ (carbon monoxide), particulate pollution ( $\mathrm{PM}_{2.5}$ and $\mathrm{PM}_{10}$; particulate matter of diameter less than $2.5 \mu \mathrm{m}$ and $10 \mu \mathrm{m}$ ), and aerosol have plummeted around the world (Berman and Ebisu, 2020; Lal et al., 2020; Muhammad et al., 2020; Shi and Brasseur, 2020; Sicard et al., 2020). Majority of the studies related to lockdown induced reduction in air-pollutant focussed over China. Studies over China invariably show a reduction in $\mathrm{CO}, \mathrm{NO}_{2}$, and $\mathrm{PM}_{2.5}$ concentrations (Bao and Zhang, 2020; Bauwens et al., 2020; Filonchyk et al., 2020; Shi and Brasseur, 2020; Wang and $\mathrm{Su}, 2020$ ). Indian region also shows a significant reduction in these air-pollutants (Gautam, 2020; Jain and Sharma, 2020; Lokhandwala and Gautam, 2020; Navinya et al., 2020b; Sharma et 
al., 2020). For example, the concentration of $\mathrm{PM}_{2.5}$ and $\mathrm{PM}_{10}$ at the surface level has reduced by $50 \%$ over Delhi (Mahato et al., 2020).

Despite an overwhelming reduction of major air-pollutants, several regions show an increase in surface $\mathrm{PM}_{2.5}$ concentration, $\mathrm{O}_{3}$ (ozone) level, aerosol loading, and hazy sky (Le et al., 2020; Li et al., 2020; Sicard et al., 2020). For example, a recent study has shown an enhanced pollution episode over Northern China, despite the cutting of significant emissions, attributable to aerosolchemistry-meteorology interaction (Le et al., 2020). During the lockdown period, over the Yangtze River Delta, residual pollutants were still high, the majority of which contributed from the industry, residential sectors, and long-range transport (Li et al., 2020). Also, over the Indian region, it is found that using space-borne observation of aerosol optical depth was non-uniform (Gautam, 2020). The aerosol loading over the Indian region is not only affected by anthropogenic pollution, but natural aerosol (such as desert dust, sea-salt) and biomass burning also contribute significantly (Vinoj et al., 2010; Pandey et al., 2016; Tiwari et al., 2016; Yang et al., 2019; Mukherjee and Vinoj, 2020). Therefore, variation in the amount of atmospheric aerosol may not necessarily follow surface pollutants. However, such large-scale changes in aerosol characteristics over one of the world's most polluted regions have the potential to modulate the radiation budget through direct, indirect, and semi-direct radiative effects and regional climate (Satheesh and Ramanathan, 2000; Vinoj and Satheesh, 2004; Pandey et al., 2020). The present study focuses explicitly on the changes in aerosol loading during the lockdown. Here, we attempt to explain the observed spatio-temporal variability of aerosol over India during the lockdown, using ground-based and space-borne aerosol observations along with aerosol and meteorological reanalysis data.

\section{DATA AND METHODS}

\subsection{MODIS}

The Moderate Resolution Imaging Spectroradiometer (MODIS) is a multichannel imager onboard NASA's Terra (EOS AM, since 1999) and Aqua (EOS PM, since 2000) satellites that provide highquality remote sensing observations of land, ocean, and atmosphere. It consists of 36 bands in the wavelength range of $0.4 \mu \mathrm{m}$ to $14.4 \mu \mathrm{m}$ that acquires data at varying spatial resolutions ( $250 \mathrm{~m}$, $500 \mathrm{~m}$, and $1 \mathrm{~km}$ ). Primary products used in the present study are aerosol, cloud parameters, and atmospheric moisture. We used daily observations of aerosol optical depth (AOD) from both MODIS Terra (MOD08_D3) and Aqua (MYD08_D3) collection 6.1 Level 3 product for the period from 2003 to 2020 (Levy et al., 2013; Wei et al., 2019a, b). In the present study, we have used a combined Dark Target (DT) Deep Blue (DB) AOD at $550 \mathrm{~nm}$, which takes advantage of both dark target (Levy et al., 2013) and deep blue (Hsu et al., 2013) algorithms. Past study over the Indian region has shown that the combined product is in better agreement with ground-based observations than the individual dark target and deep blue retrievals (Mhawish et al., 2017) and covers a larger area. The DTDB is retrieved based on the Normalized Difference Vegetation Index (NDVI) of the underlying surface, if NDVI >0.3, use DT retrievals, and if NDVI $<0.2$, use DB retrievals and if $0.2 \leq \mathrm{NDVI} \leq 0.3$ it uses the average of DT and DB provided it satisfy quality assurance criteria.

\subsection{AERONET}

Ground-based spectral AOD measurement was obtained from NASA's AERONET (AErosol RObotic NETwork) sites situated over the South Asian region. The AERONET is a global network that provides high-quality observation of aerosol properties, optical depth, angstrom exponent, single scattering albedo, etc., at high temporal resolution (Holben et al., 1998). In the present study, level-1.5 version-3.0 cloud screen daily AOD (at $550 \mathrm{~nm}$ ) observations were used. The retrieval algorithm has gone through substantial improvement in version 3 , as compared to version 2. It includes a new polarized radiative transfer code and fully automated near-real-time quality assurance (Giles et al., 2019; Sinyuk et al., 2020). AOD is the most fundamental parameter retrieved using direct sun algorithm and has an uncertainty of less than \pm 0.01 (for $\lambda>440 \mathrm{~nm}$ ) and less than \pm 0.02 (for $\lambda<440 \mathrm{~nm}$ ). Six sites (see Fig. 2(a)) were selected based on the criteria of having the AOD measurement during the lockdown period. 


\subsection{MERRA2}

The Modern-Era Retrospective Analysis for Research and Application - version 2, is a state-ofthe-art reanalysis product. It uses NASA's Goddard Earth Observing System (GEOS-5) atmospheric general circulation model and the assimilation of space-borne and ground-based observations of various meteorological parameters (Gelaro et al., 2017). The spatial resolution of the model is $0.5^{\circ} \times 0.625^{\circ}$ and 72 hybrid-eta levels from the surface up to $0.01 \mathrm{hPa}$. It simulates five aerosol species (i.e., dust, sea salt, black carbon, organic carbon, and sulfate) using GOCART (Goddard Chemistry Aerosol Radiation and Transport) module. Aerosol reanalysis products benefit from the assimilation of bias-corrected and cloud screened aerosol optical depth observed from spaceborne sensors (MODIS, AVHRR, and MISR-Multiangle Imaging SpectroRadiometer) and groundbased (i.e., AERONET) (Buchard et al., 2017; Randles et al., 2017). Aerosol reanalysis products have been widely used in past studies (McCoy et al., 2017; Pandey et al., 2017; Kramer et al., 2018; Navinya et al., 2020a).

\subsection{ERA5}

Meteorological reanalysis data used in the present study were obtained from the European Center for Medium-Range Weather Forecasts (ECMWF). Recently released, the fifth generation of ECFWF reanalysis, ERA5 (Hersbach et al., 2019), has added advantage compared to its predecessor reanalysis ERA-Interim (Dee et al., 2011). It provides data at a higher spatial and temporal resolution, a better global balance of precipitation and evaporation, improved soil moisture, more consistent sea surface temperature, and sea ice. Moreover, the troposphere is much more improved. The spatial resolution of the data is $31 \mathrm{~km}\left(\sim 0.25^{\circ}\right)$ and 137 vertical levels from the surface to $0.01 \mathrm{hPa}(\sim 80 \mathrm{~km})$. A large number of atmospheric, land, and oceanic parameters are available at a frequency of 1 hour. In the present study, we used wind speed, relative humidity, and specific humidity data.

\section{RESULTS AND DISCUSSION}

\subsection{Change in Aerosol Loading during the Lockdown}

In order to quantify the impact of lockdown on the aerosol loading, we have chosen two periods; pre-lockdown (20 $20^{\text {th }}$ February-20 ${ }^{\text {th }}$ March 2020) and during lockdown (24 ${ }^{\text {th }}$ March-22 ${ }^{\text {nd }}$ April 2020). The difference between these two periods provides the contribution due to lockdown, if any, after consideration for any climatological features. This is because, apart from the changes due to lockdown, there are inherent seasonal differences in the aerosol loading in these two selected periods. Therefore, we first discuss the climatological difference between these periods. Climatologically, the period considered as lockdown to the pre-lockdown period has significantly higher aerosol loading over South Asia (Fig. 1(c)). Especially peninsular India, the western part, east coast, and northern Bay of Bengal experience high aerosol loading. However, north India, especially the Indo Gangetic Plain (IGP), shows a slight decrease that may be a result of enhanced wind speed as a transition from winter to summer. During the year 2020, this transition shows a prevalent reduction of AOD over northern India, including Pakistan and Bangladesh, which otherwise would have increased. South India also shows a significant decrease in AOD. However, despite pan-India lockdown, mid peninsular India shows higher value compared to the pre-lockdown period. In the year 2020, aerosol loading was exceptionally higher compared to climatology (see Fig. 1(g)). Notably, the AOD anomalies were predominantly positive, except few regions, where slightly negative anomalies were observed. However, during the lockdown period over Northern and Southern India, Pakistan and Bangladesh experienced a significant reduction in AOD compared to climatology. However, anomalies over the mid-peninsular region remain positive. Therefore, Indian states, Maharastra, Telangana, Chattisgarh, and Odisha, still experienced higher aerosol loading. The difference between the two anomalies (Figs. $1(\mathrm{~g})$ and 1 (h)) gives the exact magnitude of changes due to lockdown, taking into consideration the climatology. Prevalent reduction in aerosol loading over the larger part of the Indian subcontinent is the result of reduced anthropogenic emissions of primary aerosol and precursor gases.

Analysis with MODIS onboard Aqua (afternoon satellite) and MERRA2 reanalysis data shows the spatial pattern of changes is similar to Terra (Figs. 2(a)-2(c)). For detailed analysis, the study 

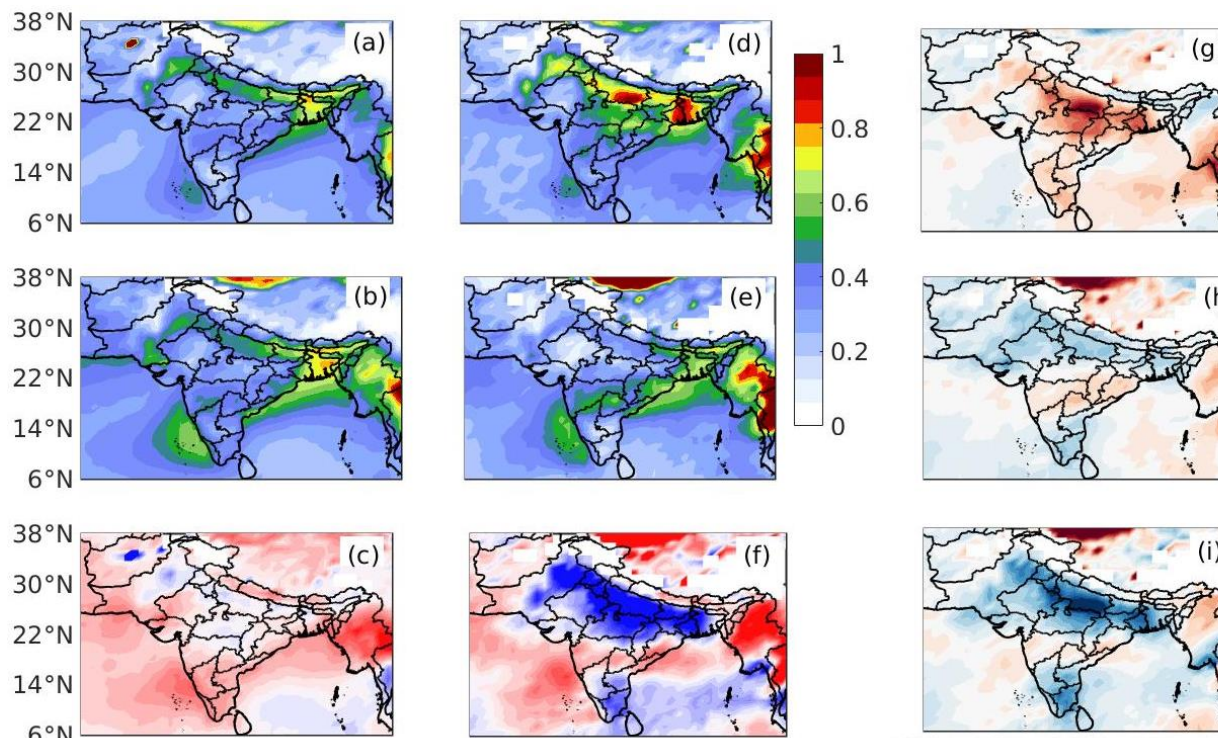

$60^{\circ} \mathrm{E} 70^{\circ} \mathrm{E} 80^{\circ} \mathrm{E} 90^{\circ} \mathrm{E} 100^{\circ} \mathrm{E} 60^{\circ} \mathrm{E} 70^{\circ} \mathrm{E} 80^{\circ} \mathrm{E} 90^{\circ} \mathrm{E} 100^{\circ} \mathrm{E}$
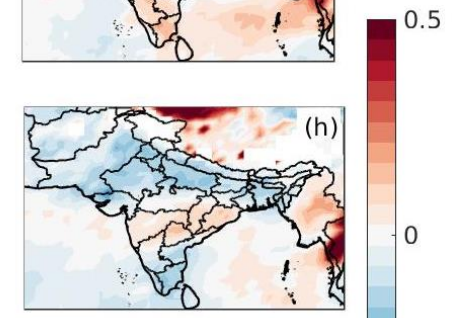

$\begin{array}{llllll}-0.3 & -0.2 & -0.1 & 0 & 0.1 & 0.2\end{array}$

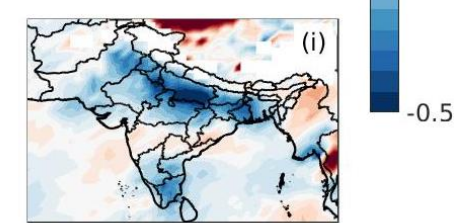

$60^{\circ} \mathrm{E} \quad 70^{\circ} \mathrm{E} \quad 80^{\circ} \mathrm{E} \quad 90^{\circ} \mathrm{E} 100^{\circ} \mathrm{E}$

Fig. 1. Aerosol optical depth during (a) pre-lockdown period (b) the lockdown and (c) difference (lockdown minus pre-lockdown) based on their climatology and same analysis for similar periods for the year 2020 (d-e and f)). (g-i) are the difference between column 2 and 1 . The data source is MODIS Terra.
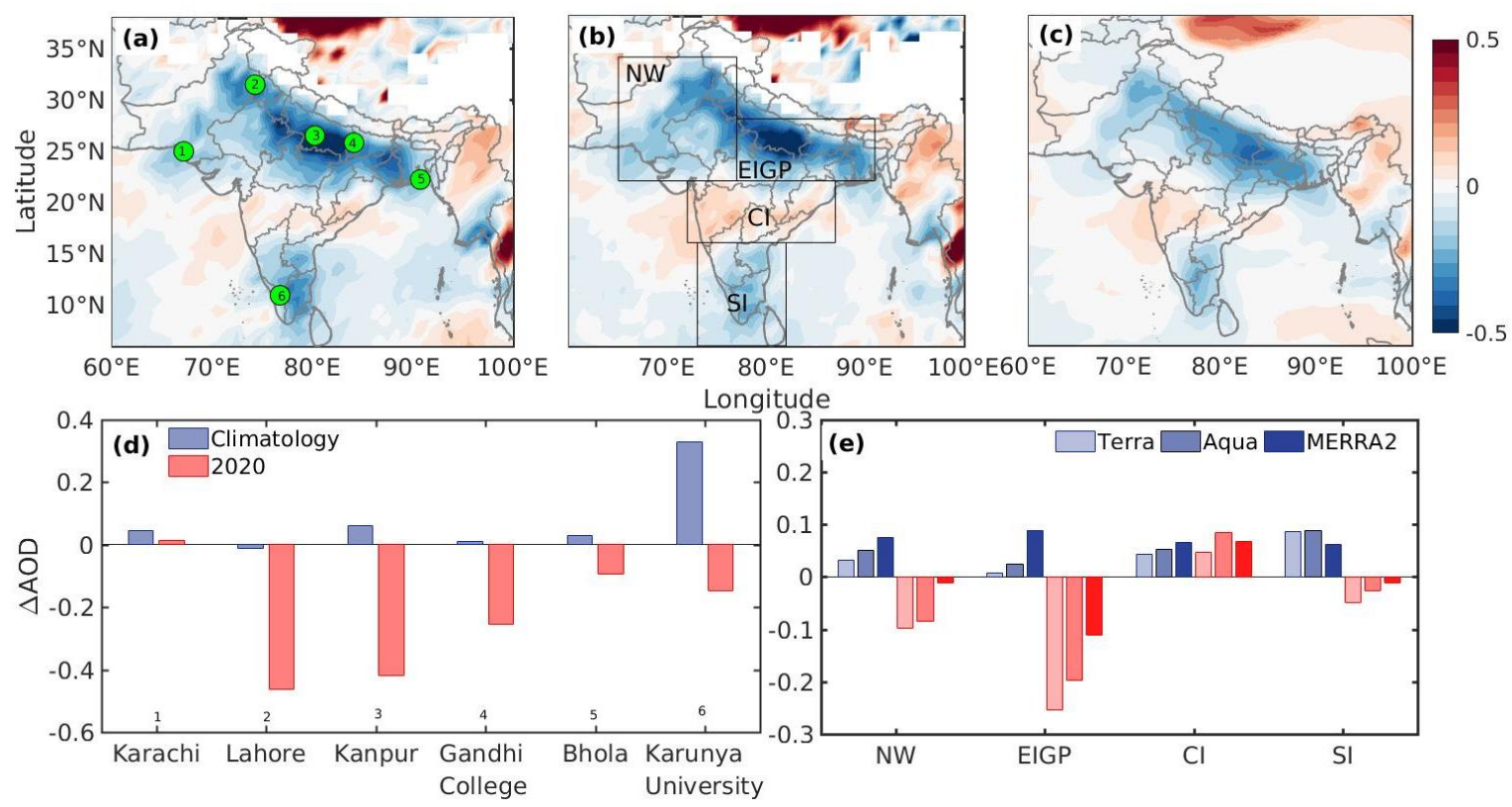

Fig. 2. Spatial pattern of changes in extinction aerosol optical depth using (a) MODIS-Terra, (b) MODIS-Aqua and (c) MERRA2 due to lockdown. The difference in AOD corresponding to lockdown and pre-lockdown period using (d) AERONET observation, and (e) Terra, Aqua, and MERRA2. Green circles are the location of AERONET sites. Blue bar represents climatology (2003-2019) and red for the year 2020 .

region was divided into four regions, namely; North West (NW), East IGP (EIGP), Central India (CI), and Southern India (SI) (Fig. 2(b)). The time series of daily averaged AOD over these regions, except $\mathrm{Cl}$, shows an abrupt decrease in AOD values following the day of lockdown announcement (Fig. S1). Climatologically, average AOD for the period corresponding to lockdown has higher AOD values across the subcontinent. AOD over NE, EIGP, and Cl shows the highest increase in MERRA2, followed by Aqua. However, over SI, this sequence is Aqua, Terra, and MERRA2. The difference 
between these two periods in the year 2020 shows a decrease except $\mathrm{Cl}$. Over NW, the percentage increase (decrease) in climatological (for the year 2020) AOD values were $9 \%(-27 \%), 16 \%(-23 \%)$, and $26 \%(-3 \%)$ for Terra, Aqua, and MERRA2, respectively. For EIGP, the most populated region shows the highest decrease in AOD $-40 \%,-32 \%$, and $-22 \%$ of the pre-lockdown period, compared to an increased of $1.6 \%, 5.8 \%$, and $24.5 \%$ in climatology. The same for SI regions are $-13 \%,-7 \%$, and $-4 \%$ in the backdrop of climatological increase of $28 \% 31 \%$ and $22 \%$. This decrease in the AOD over NW, EIGP, and SI is highest in Terra and least in the MERRA2. The $\mathrm{Cl}$ region surprisingly shows an increase in AOD obtained from all the platforms. In terms of percentage for the year 2020 , changes in AOD were $+10 \%,+20 \%$, and $+18 \%$ from Terra, Aqua, and MERRA2, respectively. However, it was $+11 \%,+14 \%$, and $+17 \%$ in the climatological average difference. The increase over $\mathrm{Cl}$ is highest in Aqua (which is expected to see more of the anthropogenic emissions due to its later overpass time). It may be noted that the percentage contribution of natural aerosols such as dust and sea-salt in the MERRA2 data is more compared to the actual amount. Past studies have reported the overestimation of dust and sea-salt (Buchard et al., 2017) and underestimation of anthropogenic aerosols (Randles et al., 2016).

The ground-based AOD over six sites has also shown a significant decrease compared to the climatological difference between periods corresponding to lockdown and pre-lockdown period. The highest reduction is observed over Lahore (-60\% of the pre-lockdown), followed by Kanpur $(-40 \%)$. However, coastal sites such as Bhola shows the smallest decrease. Karachi, a coastal site near the Arabian Sea, shows a slight increase. The decrease in the aerosol loading is on the expected line, as the lockdown posed restriction to the transport sector, closing of shops, and limits work our of several small and big companies, hence reduces primary emissions. However, all the emissions, such as from coal-driven power plants, the energy sector, pharma industry, agriculture, and other sectors, were not entirely off and contributed to remaining aerosol, apart from natural aerosols.

Despite an overall decrease in the surface pollutant and aerosol loading over the Indian region, there is a marked increase in AOD observed over central India. $\mathrm{Cl}$ is the second most polluted region after IGP in India (David et al., 2018). Identifying the possible cause for the surprising increase in AOD forms the focus of this manuscript. Both Aqua and Terra, as well as MERRA2 reanalysis, invariably show this. However, there is no AERONET (which is only publically available ground-based observations) site over this region. Multiple factors may be responsible for this increase in aerosol loadings, such as the lenient implementation of lockdown, thereby not affecting the primary emissions. However, google mobility data shows almost a similar decrease in the percentage of mobility across all Indian states (Fig. S2). It assures that the lockdown guidelines were implemented uniformly across the country, and may not be the reason for this inadvertent increase. Other possible factors for this increase is the secondary aerosol formation due to complex chemical reactions, aerosol water, and other meteorological influences. Past studies have shown that changes in surface and upper-air circulation, wind speed, boundary layer height, and atmospheric water are closely associated with the AOD variations (Vinoj and Pandey, 2016; Srivastava, 2017; Ramachandran et al., 2019). Therefore, we further examine the prevailing meteorological conditions and there changes in the next section.

\subsection{Role of Meteorology}

The prevailing wind pattern during the lockdown period over IGP was northwesterly, which turns to the southeasterly over southern India. Compared to climatology and pre-lockdown, there is a significant increase in wind speed over EIGP and SI. Apart from reduced emission, during this season, increased wind speed over IGP is associated with cleaner days due to enhances atmospheric dispersion capability (Vinoj and Pandey, 2016). Simultaneously over the Central Indian region where winds from northwest and southeast converge, a significant reduction was observed in wind speed. It appears $\mathrm{Cl}$ is receiving transport from all the regions selected in our analysis (NW, EIGP, and $\mathrm{Cl}$ ) and, at the same time, experiencing a reduction in wind speed (see Fig. 3). It was hence providing a conducive environment for the stagnation of air-pollutant over this region. Day to day variation of $A O D$ over $\mathrm{Cl}$ is associated with the wind speed over the western part (16-22N, 72-79E) of the $\mathrm{Cl}$ during the lockdown. Also, there is a slight increase in the fire count over the adjacent region (Fig. S3). 


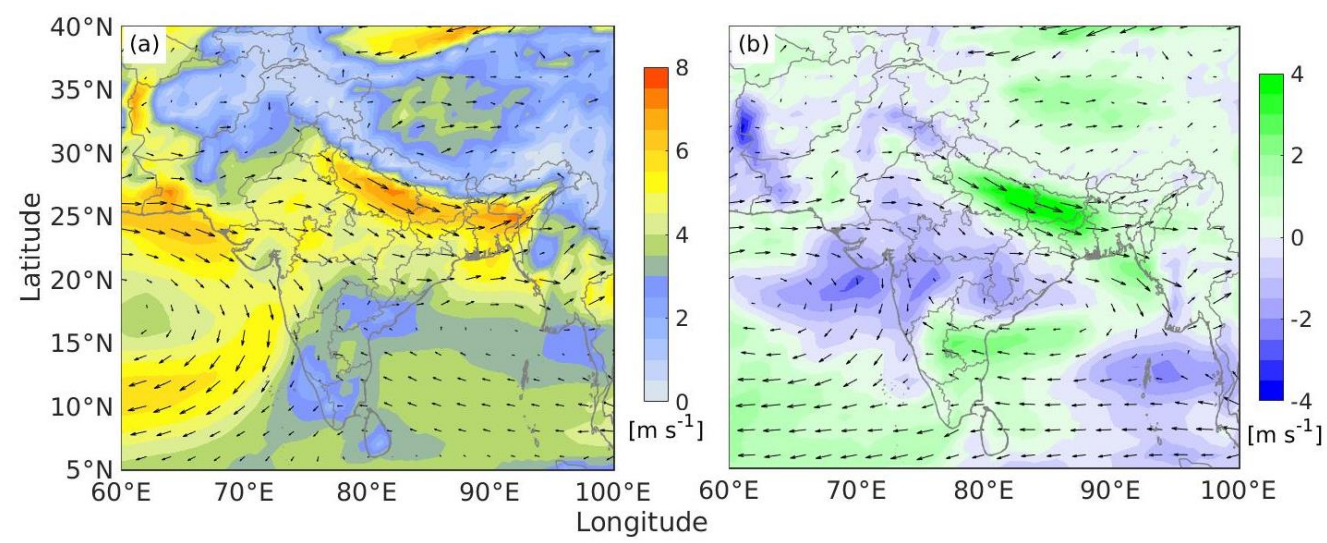

Fig. 3. (a) Climatological wind pattern (at $850 \mathrm{hPa}$ ) corresponding to lockdown period, shaded contour shows the wind speed $\left(\mathrm{m} \mathrm{s}^{-1}\right)$ (b) Changes in the wind speed compared to climatology and pre-lockdown with overlaid wind patterns during the lockdown period.

Another important atmospheric parameter that strongly influences AOD is humidity. The preexisting moisture was abnormally high, at the beginning of the lockdown over western $\mathrm{Cl}$. Both relative humidity (a measure of the degree of atmospheric saturation), and specific humidity (an indicator of the amount of actual moisture present in atmosphere) shows an increasing tendency (Figs. 4(a) and 4(b)). This increase in humidity is prominent in the mid-troposphere (700-500 hPa). Notably, the upper air RH has significantly increased (+20 in the RH unit) compared to the prelockdown period (Fig. 4(a)). The enhanced RH favors the aqueous chemistry, new particle formation, and deliquescence growth of existing particles, which in turn, may lead to an increase in AOD. The spatial pattern of the changes in the mean tropospheric humidity shows a substantial increase over west-central India (Fig. 4(c)). Day to day variability of the AOD, RH, wind speed also shows a concurrent variation during the lockdown period (Figs. 5(a) and 5(b)). The variation of $\mathrm{RH}$ and $\mathrm{AOD}$ is in the same phase, i.e., AOD increases with an increase in RH and reduced wind speed. Area average AOD (RH) has increased by $0.08 \pm 0.01$ (19.39 \pm 1.48 in RH unit), which is $21 \pm 3.3 \%(85 \pm 6.0 \%)$ of the pre-lockdown period. The wind speed has reduced by $-0.48 \pm$ $0.15 \mathrm{~m} \mathrm{~s}^{-1}$, which $-12 \pm 3.9 \%$ of pre-lockdown values. Linear regression of AOD as a function of $\mathrm{RH}$ and WS shows that an increase (decrease) in RH (WS) of $20 \mathrm{RH}$ unit $\left(1 \mathrm{~m} \mathrm{~s}^{-1}\right)$ can increase AOD by 0.10 (0.04). The increase in AOD with $\mathrm{RH}$ is in concurrence with previous studies (Yoon and Kim, 2006; Bar-Or et al., 2012; Brock et al., 2016; Zang et al., 2019; Eck et al., 2020; Li et al., 2020). The degree of change obtained using regression equation is similar to a previous study done by Yoon and Kim, 2006, an increase in RH values from 50 to $70 \%$ (in RH unit) leads to an increase in $\mathrm{AOD}$ at $550 \mathrm{~nm}$ by a factor 1.24 , which in the present study is 1.20 . The RH can explain twenty percent of daily AOD variance (Altaratz et al., 2013).

Several factors may cause an increase in AOD due to enhanced ambient moisture. For example, high humidity can increase the reaction rate of aqueous-phase oxidation of $\mathrm{SO}_{2}$ and hence increase the sulfate aerosol (Xu et al., 2019). Also, a past study has shown the rapid oxidation of $\mathrm{SO}_{2}$ over soot particles ( $\mathrm{He}$ and $\mathrm{He}, 2020$ ). It is very likely possible that $\mathrm{SO}_{2}$ emission levels may not have significantly dropped during lockdown over this region. Negligible changes were reported in the $\mathrm{SO}_{2}$ concentration over major Indian cities (Navinya et al., 2020b; Sharma et al., 2020). Also, the presence of clouds in the vicinity of the aerosol layer may enhance AOD due to the hygroscopic growth, which remains valid for all aerosol types and size ranges (Eck et al., 2014, 2020). Cloud can also illuminate the nearby aerosol particles, which falsely translate into AOD without an increase in actual aerosol amount.

In summary, a combination of factors appears to have increased AOD over this region. Increased mid-tropospheric RH and decreased wind speed along with residual emission, and favorable wind direction maintained high AOD during the lockdown. However, other factors such as biomass burning in the adjacent region and long-range transport of desert dust might have also contributed to this (see supplementary materials). In a recent study, Le et al. (2020) have also reported an interplay of atmospheric chemistry, circulation patterns, and synoptic meteorology 

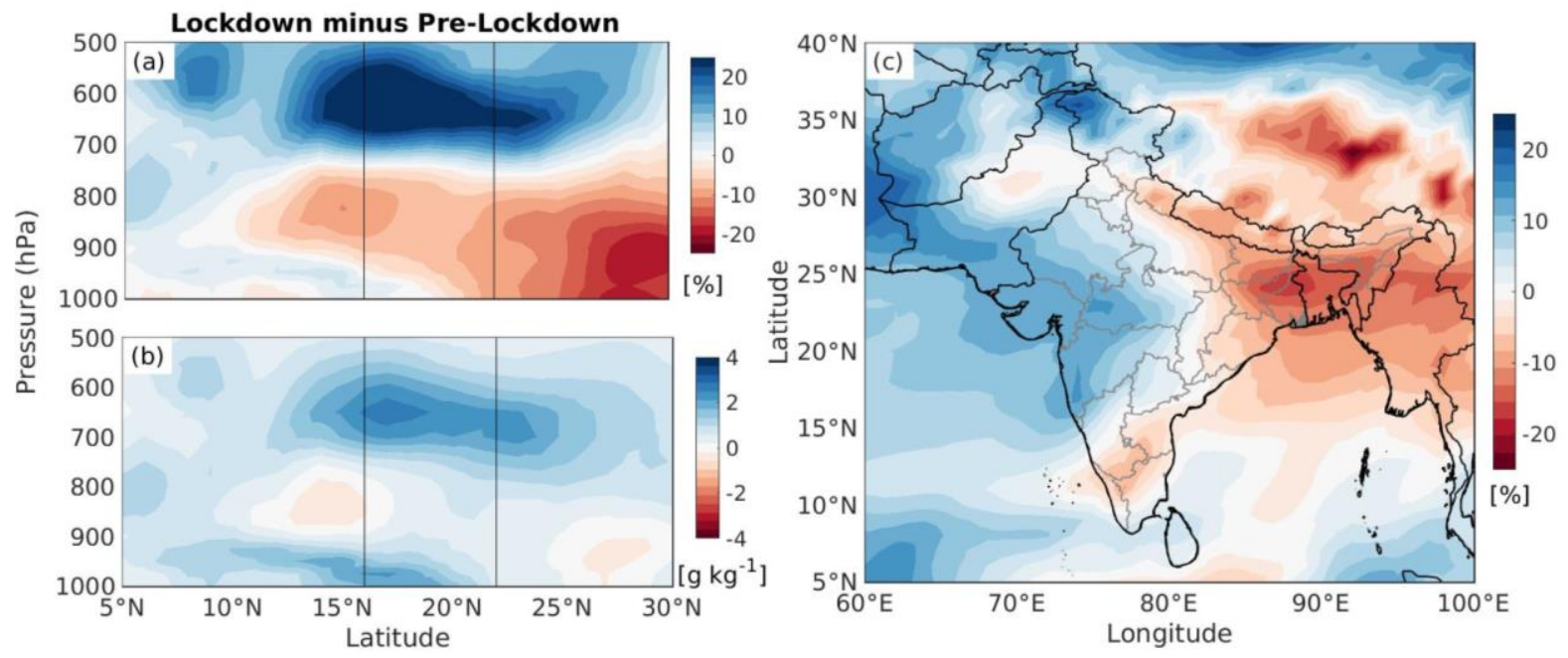

Fig. 4. Latitude-height plot of the differences (pre-lockdown minus lockdown) in (a) relative humidity and (b) specific humidity averaged over west-central India (72E-79E). Vertical lines represent the $\mathrm{Cl}$ latitudes. (c) The spatial pattern of changes in midtropospheric relative humidity $(700-500 \mathrm{hPa})$ during the lockdown.
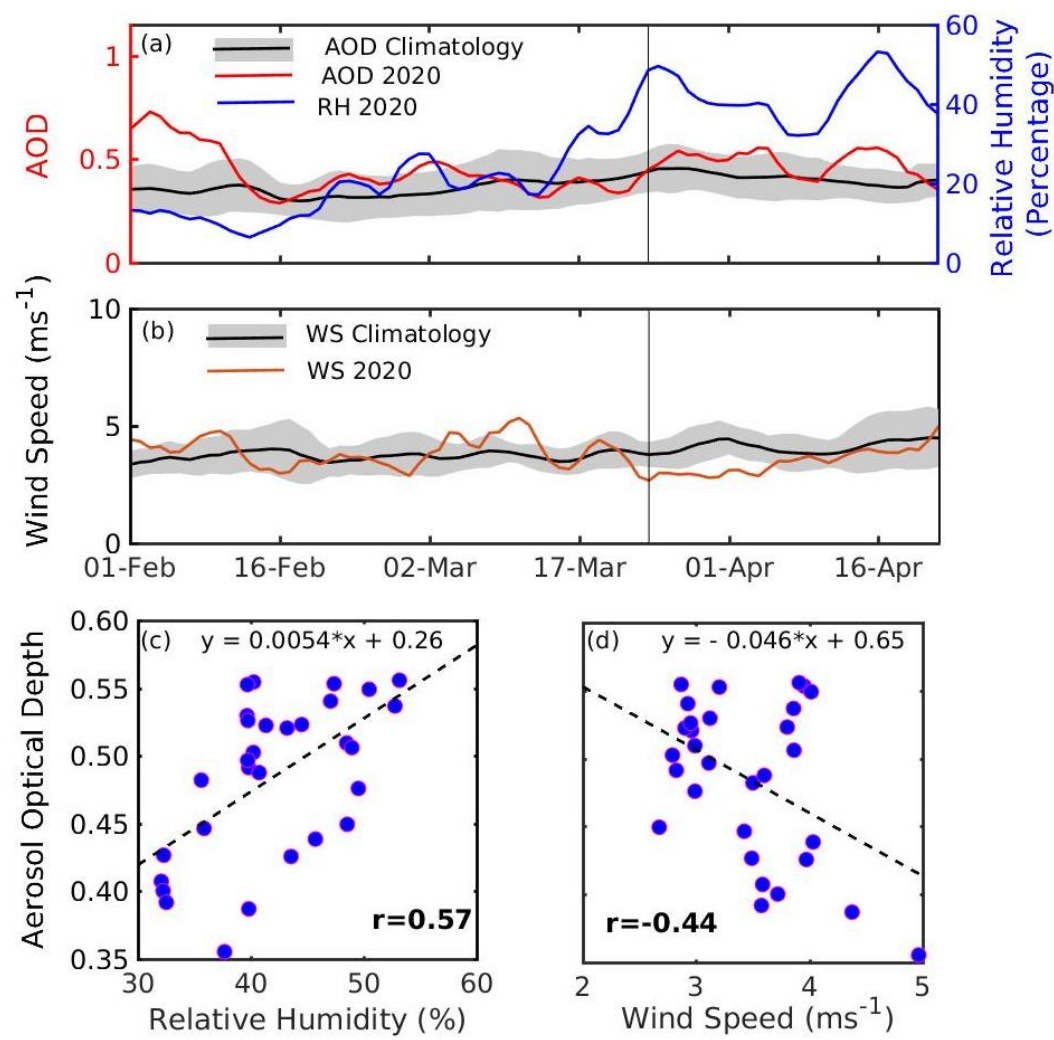

Fig. 5. Covariability of (a) AOD and mean mid-tropospheric relative humidity and (b) wind speed over Central India. The black lines (shaded region) show the intern-annual mean (standard deviation) for years 2003-2019; the vertical line shows the beginning of lockdown. Scatter plot of daily mean AOD with (c) RH and (d) wind speed during the lockdown period. Bold font for correlation coefficient $(r)$ indicates that it is statistically significant at the $99 \%$ confidence level $(p$ $<0.01)$.

to be responsible for an increase in the particulate pollution over Northern China during COVID19 lockdown. This study shows how changes in aerosol loading may change regional circulation and hence either amplify or suppress the initial change. Aerosol and their regional climate effects 
must be understood in finer details to effectively plan for mitigation efforts to optimize air quality and climate action and their benefits.

\section{SUMMARY}

1. Using space-borne observations and aerosol reanalysis products, we found that a significant decline in AOD due to lockdown over the Indian region. The highest decrease was over East IGP (up to $-40 \%$ of the pre-lockdown period), followed by NW $(-27 \%)$ and SI $(-13 \%)$. However, central India shows an increase of up to $20 \%$.

2. Ground-based measurements also show a decrease in AOD over the Indian subcontinent. The highest decline was over Lahore $(-60 \%)$, followed by Kanpur $(-52.6 \%)$ and Gandhi College $(-33.6 \%)$. AERONET stations at Bhola, near the Bay of Bengal coast, also show a decrease of $-12 \%$. Similarily, Karunya College, a site over southern peninsular India, shows a decrease of $28 \%$. However, Karachi, a coastal site near the Arabian Sea, shows an increase of $4 \%$.

3. The increase in AOD over Central India was largest from MODIS Aqua (+20\%), followed by MERRA2 (+18\%) and Terra (+10\%).

4. Our analysis shows that an increase in AOD of $0.08 \pm 0.01$ ( $21 \pm 3.3 \%$ of pre-lockdown period) accompanied by an increase in RH $19.39 \pm 1.48$ in RH unit, which is $85 \pm 6.0 \%$ of the prelockdown period. However, the wind speed has reduced by $-0.48 \pm 0.15 \mathrm{~m} \mathrm{~s}^{-1}$, which is -12 $\pm 3.9 \%$ of pre-lockdown values.

5. Daily variability of AOD over $\mathrm{Cl}$ was closely associated with variation of mid-tropospheric relative humidity and wind speed $(850 \mathrm{hPa})$ during the lockdown period. Pearson correlation coefficient of daily mean AOD with RH and wind speed $0.57(p=0.001)$ and $-0.44(p=0.01)$, respectively.

\section{ACKNOWLEDGEMENTS}

The authors are grateful to the members of the NASA Goddard Space Flight Centre, who helped with the setup and the site members who helped to maintain AERONET (https://aeronet.gsfc.na sa.gov/cgi-bin/webtool_aod_v3) sites used in the present research. Data used in this study were produced with the Giovanni online data system, developed and maintained by the NASA GES DISC (https://giovanni.gsfc.nasa.gov/giovanni/). We acknowledge the mission scientists (MODIS) and Principal Investigators who provided the data used in this research effort. Also, ECMWF (https://www.ecmwf.int/en/forecasts/datasets/reanalysis-datasets/era5) and MERRA2 (https://disc.sci.gsfc.nasa.gov/datasets?keywords=merra\&page=1\&project=MERRA-2) reanalysis acknowledged for their products. IIT Bhubaneswar is acknowledged for providing the necessary infrastructure and support to carry out this research.

\section{DISCLAIMER}

Reference to any company or specific commercial products does not constitute financial and personal conflicts of interest.

\section{SUPPLEMENTARY MATERIAL}

Supplementary data associated with this article can be found in the online version at https://doi.org/10.4209/aaqr.2020.07.0466

\section{REFERENCES}

Altaratz, O., Bar-Or, R.Z., Wollner, U., Koren, I. (2013). Relative humidity and its effect on aerosol optical depth in the vicinity of convective clouds. Environ. Res. Lett. 8, 034025. https://doi.org/10.1088/1748-9326/8/3/034025 
Bao, R., Zhang, A. (2020). Does lockdown reduce air pollution? Evidence from 44 cities in northern China. Sci. Total Environ. 731, 139052. https://doi.org/10.1016/j.scitotenv.2020.139052

Bar-Or, R.Z., Koren, I., Altaratz, O., Fredj, E. (2012). Radiative properties of humidified aerosols in cloudy environment. Atmos. Res. 118, 280-294. https://doi.org/10.1016/j.atmosres.2012.07. 014

Bauwens, M., Compernolle, S., Stavrakou, T., Müller, J.F., van Gent, J., Eskes, H., Levelt, P.F., van $\operatorname{der}$ A, R., Veefkind, J.P., Vlietinck, J., Yu, H., Zehner, C. (2020). Impact of Coronavirus Outbreak on $\mathrm{NO}_{2}$ Pollution Assessed Using TROPOMI and OMI Observations. Geophys. Res. Lett. 47, e2020GL087978. https://doi.org/10.1029/2020GL087978

Berman, J.D., Ebisu, K. (2020). Changes in U.S. air pollution during the COVID-19 pandemic. Sci. Total Environ. 739, 139864. https://doi.org/10.1016/j.scitotenv.2020.139864

Brock, C.A., Wagner, N.L., Anderson, B.E., Beyersdorf, A., Campuzano-Jost, P., Day, D.A., Diskin, G.S., Gordon, T.D., Jimenez, J.L., Lack, D.A., Liao, J., Markovic, M.Z., Middlebrook, A.M., Perring, A.E., Richardson, M.S., Schwarz, J.P., Welti, A., Ziemba, L.D., Murphy, D.M. (2016). Aerosol optical properties in the southeastern United States in summer - Part 2: Sensitivity of aerosol optical depth to relative humidity and aerosol parameters. Atmos. Chem. Phys. 16, 5009-5019. https://doi.org/10.5194/acp-16-5009-2016

Buchard, V., Randles, C.A., da Silva, A.M., Darmenov, A., Colarco, P.R., Govindaraju, R., Ferrare, R., Hair, J., Beyersdorf, A.J., Ziemba, L.D., Yu, H. (2017). The MERRA-2 Aerosol Reanalysis, 1980 onward. Part II: Evaluation and Case Studies. J. Clim. 30, 6851-6872. https://doi.org/10.1175/ JCLI-D-16-0613.1

Chauhan, A., Singh, R.P. (2020). Decline in $\mathrm{PM}_{2.5}$ concentrations over major cities around the world associated with COVID-19. Environ. Res. 187, 109634. https://doi.org/10.1016/j.envres. 2020.109634

David, L.M., Ravishankara, A.R., Kodros, J.K., Venkataraman, C., Sadavarte, P., Pierce, J.R., Chaliyakunnel, S., Millet, D.B. (2018). Aerosol optical depth over India. J. Geophys. Res. 123, 3688-3703. https://doi.org/10.1002/2017JD027719

Dee, D.P., Uppala, S.M., Simmons, A.J., Berrisford, P., Poli, P., Kobayashi, S., Andrae, U., Balmaseda, M.A., Balsamo, G., Bauer, P., Bechtold, P., Beljaars, A.C.M., van de Berg, L., Bidlot, J., Bormann, N., Delsol, C., Dragani, R., Fuentes, M., Geer, A.J., ... Vitart, F. (2011). The ERAInterim reanalysis: Configuration and performance of the data assimilation system. $\mathrm{Q}$. J. R. Meteorolog. Soc. 137, 553-597. https://doi.org/10.1002/qj.828

Eck, T.F., Holben, B.N., Kim, J., Beyersdorf, A.J., Choi, M., Lee, S., Koo, J.H., Giles, D.M., Schafer, J.S., Sinyuk, A., Peterson, D.A., Reid, J.S., Arola, A., Slutsker, I., Smirnov, A., Sorokin, M., Kraft, J., Crawford, J.F., Anderson, B.E., ... Park, S. (2020). Influence of cloud, fog, and high relative humidity during pollution transport events in South Korea: Aerosol properties and $\mathrm{PM}_{2.5}$ variability. Atmos. Environ. 232, 117530. https://doi.org/10.1016/j.atmosenv.2020.117530

Eck, T.F., Holben, B.N., Reid, J.S., Arola, A., Ferrare, R.A., Hostetler, C.A., Crumeyrolle, S.N., Berkoff, T.A., Welton, E.J., Lolli, S., Lyapustin, A., Wang, Y., Schafer, J.S., Giles, D.M., Anderson, B.E., Thornhill, K.L., Minnis, P., Pickering, K.E., Loughner, G.P., ... Sinyuk, A. (2014). Observations of rapid aerosol optical depth enhancements in the vicinity of polluted cumulus clouds. 14, 11633-11656. https://doi.org/10.5194/acp-14-11633-2014

Filonchyk, M., Hurynovich, V., Yan, H., Gusev, A., Shpilevskaya, N. (2020). Impact assessment of COVID-19 on variations of $\mathrm{SO}_{2}, \mathrm{NO}_{2}, \mathrm{CO}$ and $\mathrm{AOD}$ over East China. Aerosol Air Qual. Res. 20, 1530-1540. https://doi.org/10.4209/aaqr.2020.05.0226

Gautam, S. (2020). The influence of COVID-19 on air quality in India: A boon or inutile. Bull. Environ. Contam. Toxicol. 104, 724-726. https://doi.org/10.1007/s00128-020-02877-y

Gelaro, R., McCarty, W., Suárez, M.J., Todling, R., Molod, A., Takacs, L., Randles, C.A., Darmenov A., Bosilovich, M.G., Reichle, R., Wargan, K., Coy, L., Cullather, R., Draper, C., Akella, S., Buchard, V., Conaty, A., da Silva, A.M., Gu, W., ... Zhao, B. (2017). The modern-era retrospective analysis for research and applications, version 2 (MERRA-2). J. Clim. 30, 5419-5454. https://doi.org/10. 1175/JCLI-D-16-0758.1

Giles, D.M., Sinyuk, A., Sorokin, M.S., Schafer, J.S., Smirnov, A., Slutsker, I., Eck, T.F., Holben, B.N., Lewis, J., Campbell, J., Welton, E.J., Korkin, S., Lyapustin, A. (2019). Advancements in the Aerosol Robotic Network (AERONET) version 3 database - automated near real-time quality control algorithm with improved cloud screening for sun photometer Aerosol Optical Depth (AOD) 
Measurements. Atmos. Meas. Tech. 12, 169-209. https://doi.org/10.5194/amt-2018-272

$\mathrm{He}, \mathrm{G}$., He, $\mathrm{H}$. (2020). Water promotes the oxidation of $\mathrm{SO}_{2}$ by $\mathrm{O}_{2}$ over carbonaceous aerosols. Environ. Sci. Technol. 54, 7070-7077. https://doi.org/10.1021/acs.est.0c00021

Hersbach, H., Bell, W., Berrisford, P., Horányi, A., Sabater, J.M.S., Nicolas, J., Nicolas, M.S., Soci, C., Dee, D. (2019). Global reanalysis: goodbye ERA-Interim, hello ERA5. ECMWF NewsI. 159, 17-24. https://doi.org/10.21957/vf291hehd7

Hsu, N.C., Jeong, M.J., Bettenhausen, C., Sayer, A.M., Hansell, R., Seftor, C.S., Huang, J., Tsay, S.C. (2013). Enhanced Deep Blue aerosol retrieval algorithm: The second generation. J. Geophys. Res. 118, 9296-9315. https://doi.org/10.1002/jgrd.50712

Huang, C., Wang, Y., Li, X., Ren, L., Zhao, J., Hu, Y., Zhang, L., Fan, G., Xu, J., Gu, X., Cheng, Z., Yu, T., Xia, J., Wei, Y., Wu, W., Xie, X., Yin, W., Li, H., Liu, M., ... Cao, B. (2020). Clinical features of patients infected with 2019 novel coronavirus in Wuhan, China. Lancet 395, 497-506. https://doi.org/10.1016/S0140-6736(20)30183-5

Jain, S., Sharma, T. (2020). Social and travel lockdown impact considering coronavirus disease (COVID-19) on air quality in megacities of India: Present benefits, future challenges and way forward. Aerosol Air Qual. Res. 20, 1222-1236. https://doi.org/10.4209/aaqr.2020.04.0171

Kramer, S., Zuidema, P., Delgadillo, R., Silvia, A. da, Alvarez, C., Custals, L., Barkley, A., Gaston, C. J., Prospero, J.M. (2018). Comparison of saharan dust surface mass observations and lidar in Miami, FL, to the MERRA2 Reanalysis, in: AMS annual meeting 2018.

Lal, P., Kumar, A., Kumar, S., Kumari, S., Saikia, P., Dayanandan, A., Adhikari, D., Khan, M.L. (2020). The dark cloud with a silver lining: Assessing the impact of the SARS COVID-19 pandemic on the global environment. Sci. Total Environ. 732, 139297. https://doi.org/10.1016/j.scitotenv.2 020.139297

Le Quéré, C., Jackson, R.B., Jones, M.W., Smith, A.J.P., Abernethy, S., Andrew, R.M., De-Gol, A.J., Willis, D.R., Shan, Y., Canadell, J.G., Friedlingstein, P., Creutzig, F., Peters, G.P. (2020). Temporary reduction in daily global $\mathrm{CO}_{2}$ emissions during the COVID-19 forced confinement. Nat. Clim. Change 10, 647-653. https://doi.org/10.1038/s41558-020-0797-x

Le, T., Wang, Y., Liu, L., Yang, J., Yung, Y.L., Li, G., Seinfeld, J.H. (2020). Unexpected air pollution with marked emission reductions during the COVID-19 outbreak in China. Science 7431, 702-706. https://doi.org/10.1126/science.abb7431

Levy, R.C., Mattoo, S., Munchak, L.A., Remer, L.A., Sayer, A.M., Patadia, F., Hsu, N.C. (2013) The Collection 6 MODIS aerosol products over land and ocean. Atmos. Meas. Tech. 6, 2989-3034. https://doi.org/10.5194/amt-6-2989-2013

Li, L., Li, Q., Huang, L., Wang, Q., Zhu, A., Xu, J., Liu, Z., Li, H., Shi, L., Li, R., Azari, M., Wang, Y., Zhang, X., Liu, Z., Zhu, Y., Zhang, K., Xue, S., Ooi, M.C.G., Zhang, D., Chan, A. (2020). Air quality changes during the COVID-19 lockdown over the Yangtze River Delta Region: An insight into the impact of human activity pattern changes on air pollution variation. Sci. Total Environ. 732, 139282. https://doi.org/10.1016/j.scitotenv.2020.139282

Lokhandwala, S., Gautam, P. (2020). Indirect impact of COVID-19 on Environment: A brief study in Indian Context. Environ. Res. 188, 109807. https://doi.org/10.1016/j.envres.2020.109807

Mahato, S., Pal, S., Ghosh, K.G. (2020). Effect of lockdown amid COVID-19 pandemic on air quality of the megacity Delhi, India. Sci. Total Environ. 730, 139086. https://doi.org/10.1016/j.scitote nv.2020.139086

McCoy, D.T., Bender, F.A.M., Grosvenor, D.P., Mohrmann, J.K., Hartmann, D.L., Wood, R., Field, P.R. (2017). Predicting decadal trends in cloud droplet number concentration using reanalysis and satellite data. Atmos. Chem. Phys. 18, 2035-2047. https://doi.org/10.5194/acp-2017-811

Mhawish, A., Banerjee, T., Broday, D.M., Misra, A., Tripathi, S.N. (2017). Evaluation of MODIS Collection 6 aerosol retrieval algorithms over Indo-Gangetic Plain: Implications of aerosols types and mass loading. Remote Sens. Environ. 201, 297-313. https://doi.org/10.1016/j.rse.2 017.09.016

Muhammad, S., Long, X., Salman, M. (2020). COVID-19 pandemic and environmental pollution: A blessing in disguise? Sci. Total Environ. 728, 138820. https://doi.org/10.1016/j.scitotenv.20 20.138820

Mukherjee, T., Vinoj, V. (2020). Atmospheric aerosol optical depth and its variability over an urban location in Eastern India. Nat. Hazards. 102, 591-605. https://doi.org/10.1007/s11069. 019-03636-x 
Navinya, C.D., Vinoj, V., Pandey, S.K. (2020a). Evaluation of PM 2.5 Surface Concentrations simulated by NASA's MERRA version 2 aerosol reanalysis over india and its relation to the air quality index. Aerosol Air Qual. Res. 20, 1329-1339. https://doi.org/10.4209/aaqr.2019.12.0615

Navinya, C., Patidar, G., Phuleria, H.C. (2020b). Examining effects of the COVID-19 national lockdown on ambient air quality across urban India. Aerosol Air Qual. Res. 20, 1759-1771. https://doi.org/10.4209/aaqr.2020.05.0256

Paital, B. (2020). Nurture to nature via COVID-19, a self-regenerating environmental strategy of environment in global context. Sci. Total Environ. 729, 139088. https://doi.org/10.1016/j.scito tenv.2020.139088

Pandey, S.K., Bakshi, H., Vinoj, V. (2016). Recent changes in dust and its impact on aerosol trends over the Indo-Gangetic Plain (IGP). Proc. SPIE. Remote Sens. Atmos. Clouds, Precip. VI. 9876, 98761Z. https://doi.org/10.1117/12.2223314

Pandey, S.K., Vinoj, V., Landu, K., and Babu, S.S. (2017). Declining pre-monsoon dust loading over South Asia: Signature of a changing regional climate. Sci. Rep. 7, 16062. https://doi.org/10.10 38/s41598-017-16338-w

Pandey, S.K., Vinoj, V., Panwar, A. (2020). The short-term variability of aerosols and their impact on cloud properties and radiative effect over the Indo-Gangetic Plain. Atmos. Pollut. Res. 11, 630-638. https://doi.org/10.1016/j.apr.2019.12.017

Ramachandran, S., Rajesh, T.A., Kedia, S. (2019). Influence of relative humidity, mixed-layer height, and mesoscale vertical-velocity variations on column and surface aerosol characteristics over an urban region. Boundary Layer Meteorol. 170, 161-181. https://doi.org/10.1007/s10546018-0384-0

Randles, C.A., da Silva, A.M., Buchard, V., Colarco, P.R., Darmenov, A., Govindraju, R., Smirnov, A., Holben, B., Ferrare, R., Hair, J., Shinozuka, Y., Flynn, C.J. (2017). The MERRA-2 Aerosol reanalysis, 1980 onward. part i: system description and data assimilation evaluation. J. Clim. 30, 6823-6850. https://doi.org/10.1175/JCLI-D-16-0609.1

Randles, C.A., da Silva, A.M., Buchard, V., Darmenov, A., Colarco, P.R., Aquila, V., Bian, H., Nowottnick, E.P., Pan, X., Smirnov, A., Yu, H. (2016). The MERRA-2 aerosol assimilation. NASA Tech. Rep. Series on Global Modeling and Data Assimilation, 45.

Satheesh, S.K., Ramanathan, V. (2000). Large differences in tropical aerosol forcing at the top of the atmosphere and Earth's surface. Nature 405, 60-63. https://doi.org/10.1038/35011039

Sharma, S., Zhang, M., Anshika., Gao, J., Zhang, H., Kota, S.H. (2020). Effect of restricted emissions during COVID-19 on air quality in India. Sci. Total Environ. 72, 1315. https://doi.org/10.1016/j.s citotenv.2020.138878

Shi, X., Brasseur, G.P. (2020). The response in air quality to the reduction of Chinese economic activities during the COVID-19 outbreak. Geophys. Res. Lett. 47, e2020GL088070. https://doi.org/10.1029/2020GL088070

Sicard, P., De Marco, A., Agathokleous, E., Feng, Z., Xu, X., Paoletti, E., Rodriguez, J.J.D., Calatayud, V. (2020). Amplified ozone pollution in cities during the COVID-19 lockdown. Sci. Total Environ. 735, 139542 . https://doi.org/10.1016/j.scitotenv.2020.139542

Sinyuk, A., Holben, B.N., Eck, T.F., Giles, D.M., Slutsker, I., Korkin, S., Schafer, J.S., Smirnov, A., Sorokin, N., Lyapustin, A. (2020). The AERONET Version 3 aerosol retrieval algorithm, associated uncertainties and comparisons to Version 2. Atmos. Meas. Tech. 13, 3375-3411. https://doi.org/10.5194/amt-13-3375-2020

Srivastava, R. (2017). Trends in aerosol optical properties over South Asia. Int. J. Climatol. 37, 371-380. https://doi.org/10.1002/joc.4710

Tiwari, S., Dumka, U.C., Kaskaoutis, D.G., Ram, K., Panicker, A.S., Srivastava, M.K., Tiwari, S., Attri, S.D., Soni, V.F., Pandey, A.K. (2016). Aerosol chemical characterization and role of carbonaceous aerosol on radiative effect over Varanasi in central Indo-Gangetic Plain. Atmos. Environ. 125, 437-449. https://doi.org/10.1016/j.atmosenv.2015.07.031

Vinoj, V., Satheesh, S.K. (2004). Direct and indirect radiative effects of sea-salt aerosols over Arabian Sea. Curr. Sci. 86, 1381-1390. http://www.jstor.org/stable/24109210

Vinoj, V., Satheesh, S.K., Moorthy, K.K. (2010). Optical, radiative, and source characteristics of aerosols at Minicoy, a remote island in the southern Arabian Sea. J. Geophys. Res. 115, D01201. https://doi.org/10.1029/2009JD011810

Vinoj, V., Pandey, S.K. (2016). Towards understanding the variability of aerosol characteristics 
over the Indo-Gangetic Plain. Remote Sens. Model. Atmos. Ocean. Interact. 9882, 988205. https://doi.org/10.1117/12.2223315

Wang, Q., Su, M. (2020). A preliminary assessment of the impact of COVID-19 on environment A case study of China. Sci. Total Environ. 728, 138915. https://doi.org/10.1016/j.scitotenv.202 0.138915

Wei, J., Li, Z., Peng, Y., Sun, L. (2019a). MODIS Collection 6.1 aerosol optical depth products over land and ocean: Validation and comparison. Atmos. Environ. 201, 428-440. https://doi.org/10. 1016/j.atmosenv.2018.12.004

Wei, J., Li, Z., Sun, L., Peng, Y., Wang, L. (2019b). Improved merge schemes for MODIS Collection 6.1 Dark Target and Deep Blue combined aerosol products. Atmos. Environ. 202, 315-327. https://doi.org/10.1016/j.atmosenv.2019.01.016

World Health Organization (WHO) (2020). Coronavirus Disease 2019: Situation report-158. https://www.who.int/docs/default-source/coronaviruse/situation-reports/20200626-covid19-sitrep-158.pdf?sfvrsn=1d1aae8a_2

Xu, J., Zhu, F., Wang, S., Zhao, X., Zhang, M., Ge, X., Wang, J., Tian, W., Wang, L., Yang, L., Ding, L., Lu, X., Chen, X., Zheng, Y., Guo, Z. (2019). Impacts of relative humidity on fine aerosol properties via environmental wind tunnel experiments. Atmos. Environ. 206, 21-29. https://doi.org/10.1016/j.atmosenv.2019.03.002

Yang, L., Mukherjee, S., Pandithurai, G., Waghmare, V., Safai, P.D. (2019). Influence of dust and sea-salt sandwich effect on precipitation chemistry over the Western Ghats during summer monsoon. Sci. Rep. 9, 1-13. https://doi.org/10.1038/s41598-019-55245-0

Yoon, S.C., Kim, J. (2006). Influences of relative humidity on aerosol optical properties and aerosol radiative forcing during ACE-Asia. Atmos. Environ. 40, 4328-4338. https://doi.org/10.1016/j.at mosenv.2006.03.036

Yunus, A.P., Masago, Y., Hijioka, Y. (2020). COVID-19 and surface water quality: Improved lake water quality during the lockdown. Sci. Total Environ. 731, 139012. https://doi.org/10.1016/j. scitotenv.2020.139012

Zambrano-Monserrate, M.A., Ruano, M.A., Sanchez-Alcalde, L. (2020). Indirect effects of COVID19 on the environment. Sci. Total Environ. 728, 138813. https://doi.org/10.1016/j.scitotenv.2 020.138813

Zang, L., Wang, Z., Zhu, B., Zhang, Y. (2019). Roles of relative humidity in aerosol pollution aggravation over central China during wintertime. Int. J. Environ. Res. Public Health. 16, 4422. https://doi.org/10.3390/ijerph16224422

Zhou, P., Yang, X.L., Wang, X.G., Hu, B., Zhang, L., Zhang, W., Si, H.R., Zhu, Y., Li, B., Huang, C.L., Chen, H.D., Chen, J., Luo, Y., Guo, H., Jiang, R.D., Liu, M.Q., Chen, Y., Shen, X.R., Wang, X., ... Shi, Z.I. (2020). A pneumonia outbreak associated with a new coronavirus of probable bat origin. Nature 579, 270-273. https://doi.org/10.1038/s41586-020-2012-7 